\title{
RESPON PEMBERIAN PUPUK AB-MIX DAN BERBAGAI PUPUK ORGANIK CAIR TERHADAP PERTUMBUHAN TANAMAN TERUNG UNGU (Solanum melongena L.) SECARA HIDROPONIK DENGAN SISTEM WICK
}

\author{
Deddy Wahyudin Purba ${ }^{1 *}$, Jian Maulana ${ }^{1}$ \\ ${ }^{1}$ Fakultas Pertanian/Agroteknologi, Universitas Asahan, Indonesia \\ ${ }^{*}$ Co-author: deddy1983@yahoo.com
}

\begin{tabular}{l} 
Article Information \\
\hline History: \\
Received: $22-08-2021$ \\
Accepted: $26-10-2021$
\end{tabular}

\section{Keywords:}

AB MIX fertilizer

Organic liquid fertilizer

Solanum melongena $\mathrm{L}$.

Wick system

\begin{abstract}
Abstrak: Penelitian ini bertujuan untuk mengetahui pengaruh pupuk AB Mix dan berbagai pupuk organik cair terhadap pertumbuhan tanaman terung ungu (Solanum melongena L.) secara hidroponik dengan sistem wick. Rancangan yang digunakan adalah Rancangan Acak Kelompok (RAK). Sedangkan rancangan perlakuannya adalah faktorial yang terdiri atas dua faktor yang diteliti, yaitu: 1 . Pupuk AB Mix (A) terdiri dari 3 taraf A1 : 500 ppm/plot, A2 : 100 ppm/plot, A3 : 1500/plot. 2. Berbagai pupuk organik cair (C) dengan dosis $40 \mathrm{cc} / \mathrm{plot}$ : C1 (POC Kulit Buah), C2 (POC HANTU), C3 (POC Bonggol Pisang), dengan 3 kali ulangan. Parameter Pengamatan yang diamati adalah tinggi tanaman $(\mathrm{cm})$, diameter batang $(\mathrm{mm})$, jumlah daun (helai), umur berbunga (hari), dan jumlah bunga (tangkai). Hasil penelitian menunjukkan bahwa pupuk AB Mix menunjukkan pengaruh yang tidak nyata pada pengamatan tinggi tanaman dan diameter batang, tetapi berpengaruh nyata pada pengamatan jumlah daun, umur berbunga dan jumlah bunga. Pemberian berbagai pupuk organik cair tidak menunjukkan pengaruh yang nyata hampir di semua parameter amatan kecuali pada pengamatan umur berbunga yang menunjukkan pengaruh yang nyata dan memperoleh hasil pupuk organik cair terbaik, yaitu POC Bonggol Pisang (C3). Selain itu, interaksi pupuk AB Mix dan berbagai pupuk organik cair tidak berpengaruh nyata pada semua parameter pengamatan.
\end{abstract}

\section{A. LATAR BELAKANG}

Manusia membutuhkan sayuran untuk memenuhi kelengkapan vitamin, protein dan kebutuhan hidup yang lain. Terung ungu (Solanum melongena L.) termasuk jenis tanaman sayuran buah semusim. Terung digolongkan sebagai tanaman semusim karena hanya berproduksi satu kali. Terung sebagai bahan makanan sayuran sangat dibutuhkan oleh masyarakat untuk menu makanan sehari-hari. Bahkan lebih dari itu, terung juga sangat dibutuhkan oleh masyarakat sebagai bahan obat untuk beberapa jenis penyakit (Aisyah, 2020).

Terung ungu (Solanum Melongena L.) merupakan komoditas pertanian yang penting dibutuhkan di Indonesia, hal ini disebabkan oleh terung mempunyai kandungan gizi cukup lengkap dan mempunyai nilai ekonomis tinggi. Biasanya digunakan sebagai bahan makanan, bahan terapi, dan bahan kosmetik alami. Tanaman terung banyak mengandung kalium dan vitamin A yang dapat berguna bagi tubuh. Komposisi kimia terung per $100 \mathrm{~g}$ yaitu air 92,70 g; abu (mineral) o,60 g; besi $0,60 \mathrm{mg}$; karbohidrat $5,70 \mathrm{~g}$; lemak $0,20 \mathrm{~g}$; serat $0,80 \mathrm{~g}$; kalori 24,00 kal; fosfor 27,00 mg; kalium 223,00 $\mathrm{mg}$; kalsium 30,00 $\mathrm{mg}$; protein $1,10 \mathrm{~g}$; natrium 4,00 $\mathrm{mg}$; vitamin B3 o,6o mg; vitamin B2 0,05 mg; vitamin B1 10,00 mg; vitamin A 130,00 SI; dan vitamin C 5,00 mg (Prastya and Palupi, 2017),

Sistem budidaya sayuran yang dilakukan masyarakat Indonesia umumnya secara konvensional. Upaya peningkatan produktivitas dan kualitas sayuran secara konvensional telah banyak dilakukan oleh petani meskipun hasilnya kurang memuaskan. Hidroponik 
merupakan salah satu sistem budidaya pertanian yang digunakan untuk memperbaiki kualitas sayuran yang dihasilkan. Hidroponik dapat didefinisikan sebagai sistem budidaya tanaman dengan menggunakan media selain tanah, tetapi mengunakan media bersifat inert seperti kerikil, pasir, gambut, vermikulit, batu apung atau serbuk gergaji dan ditambahkan larutan hara yang berisi seluruh unsur yang dibutuhkan bagi pertumbuhan tanaman (Purba and Patimah, 2020).

Pupuk organik sangat bermanfaat bagi peningkatan produksi pertanian baik kualitas maupun kuantitas, mengurangi pencemaran lingkungan, meningkatkan kualitas lahan secari berkelanjutan, dan dapat mencegah degradasi lahan. Sumber bahan untuk pupuk organik sangat beraneka ragam, dengan karekteristik fisik dan kandungan kimia yang sangat beragam sehingga pengaruh dari penggunaan pupuk organik terhadap lahan dan tanaman dapat bervariasi. Selain itu, peranannya cukup besar terhadap perbaikan sifat fisika, kimia, biologi tanah serta lingkungan. Pupuk organik yang ditambahkan ke dalam tanah akan mengalami beberapa kali fase perombakan oleh mikro organisme tanah untuk menjadi humus. Bahan organik juga berperan sebagai sumber energi dan makanan mikroba tanah sehingga dapat meningkatkan aktivitas mikroba tersebut dalam penyediaan hara tanaman (Habibie, 2020).

Nutrisi sangat penting untuk keberhasilan dalam menanam secara hidroponik, karena tanpa nutrisi tentu saja tidak bisa menanam secara hidroponik. Nutrisi merupakan hara makro dan mikro yang harus ada untuk pertumbuhan tanaman. Setiap jenis nutrisi memiliki komposisi yang berbeda-beda. AB mix merupakan salah satu pupuk yang dapat dijadikan larutan hara pada sistem hidroponik. Pupuk ini terdiri dari dua bagian yakni stok A berupa unsur hara makro sedangkan stok B berupa unsur hara mikro. Rekomendasi produsen pupuk tersebut bahwa pupuk ini sebagai larutan hara sayuran daun dan sayuran buah, khusus untuk sayuran daun dianjurkan menggunakan AB Mix Stok A dan B masing-masing dengan konsentrasi $5 \mathrm{ml} / \mathrm{L}$ air (Purba, Safruddin and Gunawan, 2019).

Bonggol pisang mengandung karbohidrat (66\%), protein, air, dan mineral-mineral penting. Bonggol pisang mempunyai kandungan pati 45,4\% dan kadar protein $4,35 \%$. Bonggol pisang mengandung mikroba pengurai bahan organik antara lain Bacillus $s p$, Aeromonas sp, dan Aspergillus zigger. Mikroba inilah yang biasa menguraikan bahan organik, atau akan bertindak sebagai dekomposer bahan organik yang akan dikomposkan (Chaniago, Purba and Utama, 2017).

Keberadaan sampah buah-buahan yang melimpah memiliki potensi yang besar sebagai sumber bahan baku untuk pembuatan pupuk organik cair. Tumpukan limbah buah-buahan ini jarang dimanfaatkan oleh masyarakat, karena sudah tidak layak untuk makanan ternak. Biasanya sampah buah-buahan hanya dibiarkan saja, sehingga menimbulkan aroma yang kurang sedap bagi kebersihan lingkungan dan dapat mengganggu kesehatan. Sebagai solusi dari dampak yang ditimbulkan oleh sampah buah-buahan ini, limbah kulit buah-buahan ini dapat dijadikan sumber bahan baku alternatif yang potensial untuk menghasilkan pupuk organik cair. Di samping itu, teknologi ini juga banyak keuntungan, yaitu bubur sampah buah-buahan, air lindinya dapat digunakan sebagai pupuk organik cair dan ampasnya dapat dijadikan media pertumbuhan (media sapih). Pupuk organik yang dihasilkan adalah pupuk yang sangat kaya akan unsur-unsur yang dibutuhkan oleh tanaman. Bahkan, senyawa-senyawa tertentu seperti protein, selulose, lignin, dan lain-lain tidak bisa digantikan oleh pupuk kimia (Marjenah et al., 2018).

Pupuk organik cair HANTU adalah pupuk yang terbuat dari sari tumbuhan alami (herbal) berbentuk cair. Salah satu merek dagang adalah Hormon Tanaman Unggul. Pupuk HANTU Multiguna Exclusive ini berwarna putih kelabu. Pupuk ini juga dapat membantu mempercepat pertumbuhan dan perkembangan tanaman, hal ini disebabkan karena selain mengandung unsur hara makro dan mikro, pupuk ini juga mengandung hormon pertumbuhan tanaman. Pupuk ini juga mempercepat keluarnya bunga, mempercepat masa panen sehingga panen lebih cepat dari biasanya. Pemakaian pupuk organik Hormon Tanaman Unggul untuk jenis sayur-mayur seperti asparagus, buncis, kacang panjang, cabai, bawang merah, bawang putih, seledri, dan lain-lain, direkomendasikan menggunakan dosis $2 \mathrm{ml}$ dicampurkan dengan 1 liter air (Suhendra, Safruddin and Gunawan, 2019).

Dari uraian di atas, maka penulis telah melakukan penelitian dengan mengkombinasikan penggunaan Pupuk AB Mix dengan berbagai pupuk organik cair, untuk memeperoleh hasil kombinasi pupuk yang optimal pada pertumbuhan dan produksi tanaman terung ungu secara hidroponik dengan sistem wick. Tujuan penelitian ini adalah untuk mengetahui pengaruh pemberian pupuk AB-Mix dan berbagai pupuk organik cair terhadap pertumbuhan tanaman terung ungu secara hidroponik dengan sistem wick.

\section{B. METODE PENELITIAN}

Penelitian ini telah dilaksanakan di rumah hidroponik Fakultas Pertanian Universitas Asahan, dengan ketinggian tempat $\pm 11 \mathrm{~m}$ di atas permukaan laut. Penelitian ini telah dilakukan pada bulan Desember 2020 s/d Februari 2021.

Bahan-bahan yang digunakan pada penelitian ini adalah benih terung ungu varietas Lezata $\mathrm{F}$, rockwool, pupuk AB Mix, POC Kulit Buah, POC Bonggol pisang, POC Hantu Ijo Royo, fungisida bahan aktifmankozeb dan insektisida bahan aktif delta metrin. Alat-alat yang 
digunakan antara lain: Sterofoam buah, plastik terpal, kain flanel, netpot (cup es krim), TDS meter, PH meter, ember, ajiran (tali rafiah), meteran, alat tulis, kalkulator dan alat lain yang diperlukan.

Penelitian ini menggunakan Rancangan Acak Kelompok (RAK) Faktorial dengan 2 faktor, yaitu :

1. Faktor konsentrasi pupuk $\mathrm{AB}$ Mix dengan 3 taraf, yaitu :

$$
\begin{aligned}
\mathrm{A} 1 & =500 \mathrm{ppm} / \text { sterofoam } \\
\mathrm{A} 2 & =1000 \mathrm{ppm} / \text { sterofoam } \\
\mathrm{A} 3 & =1500 \mathrm{ppm} / \text { sterofoam }
\end{aligned}
$$

2. Faktor berbagai jenis pupuk Organik Cair dengan konsentrasi $40 \mathrm{cc} /$ plot dengan 3 taraf, yaitu :

$$
\begin{aligned}
& \mathrm{C}_{1}=\text { POC Kulit Buah } \\
& \mathrm{C}_{2}=\text { POC HANTU } \\
& \mathrm{C}_{3}=\text { POC Bonggol pisang }
\end{aligned}
$$

Adapun parameter yang diamati adalah tinggi tanaman $(\mathrm{cm})$, diameter batang $(\mathrm{mm})$, jumlah daun (helai), umur berbunga (hari) dan jumlah bunga (tangkai).

\section{HASIL DAN PEMBAHASAN}

\section{Tinggi Tanaman.}

Dari hasil analisis sidik ragam dapat dilihat bahwa pemberian pupuk AB Mix dan pupuk organik cair tidak menunjukkan pengaruh yang nyata terhadap tinggi tanaman terung ungu pada umur 2, 4 dan 6 minggu setelah tanam. Interaksi pupuk $\mathrm{AB}$ Mix dan berbagai pupuk organik cair menunjukkan tidak pengaruh nyata pada umur 2, 4 dan 6 minggu setalah tanam.

Hasil uji beda rataan pengaruh pupuk AB Mix dan berbagai pupuk organik cair terhadap tinggi tanaman terung ungu pada umur 6 minggu setelah tanam dapat dilihat pada Tabel 1 berikut ini.

Tabel 1.

Rataan Tinggi Tanaman Terung Ungu

\begin{tabular}{ccccc}
\hline $\mathrm{A} / \mathrm{C}$ & $\begin{array}{c}\mathrm{C}_{1} \\
(\mathrm{~cm})\end{array}$ & $\begin{array}{c}\mathrm{C}_{2} \\
(\mathrm{~cm})\end{array}$ & $\begin{array}{c}\mathrm{C}_{3} \\
(\mathrm{~cm})\end{array}$ & $\begin{array}{c}\text { Rerata } \\
(\mathrm{cm})\end{array}$ \\
\hline $\mathrm{A}_{1}$ & 18,90 & 20,75 & 20,92 & $20,19 \mathrm{a}$ \\
$\mathrm{A}_{2}$ & 20,83 & 26,70 & 19,95 & $22,49 \mathrm{a}$ \\
$\mathrm{A}_{3}$ & 25,08 & 21,67 & 23,07 & $23,27 \mathrm{a}$ \\
\hline Rerata & $21,61 \mathrm{a}$ & $23,04 \mathrm{a}$ & $21,31 \mathrm{a}$ & KK 12.90 \\
\hline
\end{tabular}

Dari Tabel 1 dapat dilihat bahwa pemberian pupuk AB Mix secara tunggal dengan perlakuan $1500 \mathrm{ppm} / \mathrm{plot}$ (A3) memperoleh hasil tinggi tanaman tertinggi yaitu $23,27 \mathrm{~cm}$, tidak berbeda nyata dengan perlakuan A2 1000 ppm/plot (22,49 $\mathrm{cm})$ dan perlakuan A1500 pp/plot $(20,19 \mathrm{~cm})$. Demikian juga dengan perlakuan A1 dan A3 menunjukkan tidak berbeda nyata.

Pemberian berbagai pupuk organik cair HANTU secara tunggal dengan dosis 40cc/plot (C2) memperoleh hasil tanaman tertinggi yaitu 23,04 cm, tidak berbeda nyata dengan perlakuan pupuk organik cair kulit buah (C1) yaitu 21,61 cm, dan juga perlakuan pupuk organik cair bonggol pisang (C3) dengan tinggi tanaman 21,31 cm. Sedangkan perlakuan $\mathrm{C} 1$ dengan $\mathrm{C} 3$ juga menunjukkan tidak pengaruh nyata. Interaksi pemberian pupuk $\mathrm{AB}$ Mix dan berbagai pupuk organic cair menunjukkan pengaruh tidak nyata. Sangat nyata tinggi tanaman tertinggi didapatkan pada kombinasi perlakuan $\mathrm{A} 2 \mathrm{C} 2 \neg$, yaitu dengan tinggi tanaman terung ungu mencapai $26,70 \mathrm{~cm}$.

\section{Diameter batang}

Dari hasil analisis sidik ragam dapat dilihat bahwa pemberian pupuk AB Mix dan pupuk organik cair menunjukkan tidak pengaruh nyata terhadap diameter batang terung ungu umur 2, 4 dan 6 minggu. Interaksi pupuk AB Mix dengan berbagai pupuk organik cair menunjukkan tidak pengaruh nyata pada umur 2, 4, dan 6 minggu setelah tanam. Hasil uji beda rerata pengaruh pupuk AB Mix dan berbagai pupuk organik cair terhadap diameter batang terung ungu umur 6 minggu setelah tanam dapat dilihat pada Tabel 2 berikut ini.

Tabel 2.

Diameter Batang Tanaman Terung Ungu

\begin{tabular}{ccccc}
\hline $\mathrm{A} / \mathrm{C}$ & $\begin{array}{c}\mathrm{C}_{1} \\
(\mathrm{~mm})\end{array}$ & $\begin{array}{c}\mathrm{C}_{2} \\
(\mathrm{~mm})\end{array}$ & $\begin{array}{c}\mathrm{C}_{3} \\
(\mathrm{~mm})\end{array}$ & $\begin{array}{c}\text { Rerata } \\
(\mathrm{mm})\end{array}$ \\
\hline $\mathrm{A}_{1}$ & 5,86 & 6,30 & 6,13 & $6,09 \mathrm{a}$ \\
$\mathrm{A}_{2}$ & 5,82 & 6,30 & 6,09 & $6,07 \mathrm{a}$ \\
$\mathrm{A}_{3}$ & 6,63 & 6,35 & 6,02 & $6,33 \mathrm{a}$ \\
\hline Rerata & $6,10 \mathrm{a}$ & $6,31 \mathrm{a}$ & $6,08 \mathrm{a}$ & $\mathrm{KK}=22,50$ \\
\hline
\end{tabular}

Dari Tabel 2 dapat dilihat bahwa pemberian pupuk AB Mix secara tunggal dengan perlakuan A3= $1500 \mathrm{ppm} /$ plot memiliki diameter batang terbesar yaitu $6,33 \mathrm{~mm}$, tidak berbeda nyata dengan perlakuan A2=1000 ppm/plot $(6,07 \mathrm{~mm})$ dan perlakuan $\mathrm{A} 1=1000 \mathrm{ppm} / \mathrm{plot}(6,09 \mathrm{~mm})$. Sedangkan perlakuan A1 dan A2 tidak menunjukkan pengaruh nyata. Pemberian berbagai pupuk organik cair secara tunggal dengan dosis $40 \mathrm{cc} / \mathrm{plot}$ menghasilkan diameter batang terbesar pada perlakuan $\mathrm{C}_{2}$ = pupuk organik cair HANTU yaitu 6,31 mm, tidak berbeda nyata dengan perlakuan $\mathrm{C} 1=$ pupuk organik cair kulit buah $(6,10 \mathrm{~mm})$, dan perlakuan $\mathrm{C}_{3}=$ pupuk organik cair bonggol pisang (6,08 mm). Begitu juga antara $\mathrm{C}_{1}$ dengan $\mathrm{C}_{3}$ menunjukkan pengaruh tidak berbeda nyata. Interaksi pemberian pupuk $\mathrm{AB}$ Mix dan berbagai pupuk organik cair menunjukkan pengaruh yang tidak nyata. Secara visual diameter batang terbesar diperoleh pada kombinasi perlakuan $\mathrm{A} 3 \mathrm{C} 1$, yaitu $6,63 \mathrm{~mm}$.

\section{Jumlah Daun}

Dari hasil analisis sidik ragam dapat dilihat bahwa pemberian pupuk AB Mix menunjukkan pengaruh yang tidak berbeda nyata terhadap jumlah daun terung ungu umur 2 dan 4 minggu setelah tanam, tetapi berpengaruh nyata pada umur 6 
minggu setelah tanam. Pemberian berbagai pupuk organik cair menunjukkan pengaruh yang tidak berbeda nyata terhadap jumlah daun terung ungu umur 2, 4 dan 6 minggu setelah tanam. Interaksi pupuk AB Mix dengan berbagai pupuk organik cair terhadap jumlah daun terung ungu juga menunjukkan pengaruh yang tidak berbeda nyata pada umur 2, 4 dan 6 minggu setelah tanam.

Hasil uji beda rerata pengaruh pupuk AB Mix dan berbagai pupuk organik cair terhadap jumlah daun terung ungu umur 6 minggu setelah tanam dapat dilihat pada Tabel 3 berikut ini.

Tabel 3.

Jumlah Daun Tanaman Terung Ungu

\begin{tabular}{ccccc}
\hline $\mathrm{A} / \mathrm{C}$ & $\begin{array}{c}\mathrm{C}_{1} \\
\text { (helai) }\end{array}$ & $\begin{array}{c}\mathrm{C}_{2} \\
\text { (helai) }\end{array}$ & $\begin{array}{c}\mathrm{C}_{3} \\
\text { (helai) }\end{array}$ & $\begin{array}{c}\text { Rerata } \\
\text { (helai) }\end{array}$ \\
\hline $\mathrm{A}_{1}$ & $11, \mathrm{OO}$ & 11,00 & 11,00 & $11,00 \mathrm{~b}$ \\
$\mathrm{~A}_{2}$ & 12,00 & 12,00 & 11,00 & $11,00 \mathrm{~b}$ \\
$\mathrm{~A}_{3}$ & 12,00 & 12,00 & 12,00 & $12,00 \mathrm{a}$ \\
\hline Rerata & $12,00 \mathrm{a}$ & $11,00 \mathrm{a}$ & $11,00 \mathrm{a}$ & $\mathrm{Kk}=4,38 \%$ \\
\hline
\end{tabular}

Dari Tabel 3 dapat dilihat bahwa pemberian pupuk $\mathrm{AB}$ Mix secara tunggal dengan perlakuan $1500 \mathrm{ppm} / \mathrm{plot}$ (A3) menghasilkan jumlah daun terbanyak yaitu 12,00 helai, berbeda nyata dengan perlakuan A2= $1000 \mathrm{ppm} /$ plot (11,94 helai) dan A1= $500 \mathrm{ppm} / \mathrm{plot}(11,50$ helai), sedangkan antara perlakuan A2 dan A1 menunjukkan tidak berbeda nyata. Pemberian berbagai pupuk organik cair secara tunggal dengan dosis $40 \mathrm{cc} /$ plot $(\mathrm{C} 1)$ pupuk organik cair kulit buah menghasilkan jumlah daun terbanyak yaitu 12,17 helai, tidak berbeda nyata dengan perlakuan pupuk organik cair HANTU(C2) = 11,83 helai dan perlakuan pupuk organik cair bonggol pisang $\left(\mathrm{C}_{3}\right)$, sedangkan perlakuan $\mathrm{C}_{2}$ dengan $\mathrm{C}_{3}$ menunjukkan saling tidak berbeda nyata. Interaksi pemberian pupuk $\mathrm{AB}$ Mix dan berbagai pupuk organik cair menunjukkan pengaruh yang tidak nyata. Secara visual jumlah daun terbanyak didapat pada kombinasi perlakuan A2C1 yaitu 12,50 helai. Pengaruh pupuk AB Mix terhadap jumlah daun terung ungu umur 6 minggu setelah tanam dapat dilihat pada kurva (Gambar 1) di bawah ini.

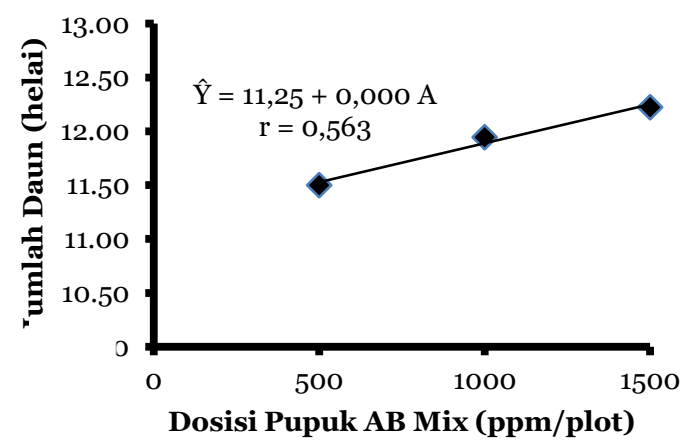

Gambar 1. Kurva Pengaruh Pupuk AB Mix Terhadap Jumlah Daun (helai)Terung Ungu Umur 6 Minggu Setelah Tanam.
Analisis regresi pengaruh pemberian pupuk $\mathrm{AB}$ Mix terhadap jumlah daun terung ungu umur 6 minggu setelah tanam diperoleh kurva regresi linier dengan persamaan $\hat{Y}=11,25+0,000 \mathrm{~A}$ dengan $\mathrm{r}=$ 0,563 seperti dapat dilihat pada Gambar 1 di atas.

\section{Umur Berbunga}

Dari hasil analisis sidik ragam dapat dilihat bahwa pemberian pupuk AB Mix menunjukkan pengaruh yang nyata terhadap umur berbunga terung ungu. Sedangkan interaksi pupuk AB Mix dengan berbagai pupuk organik cair menunjukkan pengaruh yang tidak nyata pada umur berbunga terung ungu.

Hasil uji beda rerata pengaruh pupuk $\mathrm{AB}$ Mix dan berbagai pupuk organik cair terhadap umur berbunga terung ungu dapat dilihat pada Tabel 4 berikut ini.

Tabel 4 .

Umur Berbunga Tanaman Terung Ungu

\begin{tabular}{ccccc}
\hline $\mathrm{A} / \mathrm{C}$ & $\begin{array}{c}\mathrm{C}_{1} \\
\text { (hari) }\end{array}$ & $\begin{array}{c}\mathrm{C}_{2} \\
\text { (hari) }\end{array}$ & $\begin{array}{c}\mathrm{C}_{3} \\
\text { (hari) }\end{array}$ & $\begin{array}{c}\text { Rerata } \\
\text { (hari) }\end{array}$ \\
\hline $\mathrm{A}_{1}$ & 52,00 & 50,00 & 51,00 & $51,00 \mathrm{a}$ \\
$\mathrm{A}_{2}$ & 42,00 & 41,00 & 40,00 & $41,00 \mathrm{~b}$ \\
$\mathrm{~A}_{3}$ & 32,00 & 30,00 & 29,00 & $30,33 \mathrm{c}$ \\
\hline Rerata & $42,00 \mathrm{a}$ & $40,33 \mathrm{~b}$ & $40,00 \mathrm{~b}$ & $\mathrm{KK}=4,23 \%$ \\
\hline
\end{tabular}

Dari Tabel 4 diatas dapat dilihat bahwa pemberian pupuk $\mathrm{AB}$ Mix secara tunggal dengan perlakuan $1500 \mathrm{ppm} /$ plot (A3) menghasilkan umur berbunga tercepat yaitu 30,33 hari, berbeda nyata dengan perlakuan A2 (1000 ppm/plot $)=41,00$ hari, dan A1 (500 ppm/plot) $=51,00$ hari. Demikian pula dengan perlakuan A2 dan A1 menunjukkan saling berbeda nyata. Pemberian berbagai pupuk organik secara tunggal dengan dosis 40cc/plot ( $\mathrm{C}_{3}$ ) pupuk organik cair bonggol pisang menghasilkan umur berbunga tercepat yaitu 40,00 hari, tidak berbeda nyata dengan C2 (pupuk organik cair HANTU) 40,33 hari, namun berbeda nyata dengan $\mathrm{C} 1$ (pupuk organik cair kulit buah) 42,00 hari. Selain itu, perlakuan $\mathrm{C}_{2}$ juga berbeda nyata dengan $\mathrm{C} 1$. Interaksi pemberian pupuk $\mathrm{AB}$ Mix dan berbagai pupuk organik cair menunjukkan pengaruh yang tidak berbeda nyata. Secara visual umur berbunga tercepat diperoleh pada kombinasi perlakuan $\mathrm{A}_{3} \mathrm{C}_{3}$ ᄀ, yaitu dengan umur 29,33 hari. Pengaruh pupuk $A B$ Mix terhadap umur berbunga terung ungu dapat dilihat pada kurva Gambar 2. Dimana, analisis regresi pengaruh pemberian pupuk $\mathrm{AB}$ Mix terhadap umur berbunga terung ungu diperoleh kurva regresi linier dengan persamaan $\hat{\mathrm{Y}}=59,667+0,018 \mathrm{~A}$ dengan $r=0,99$. 


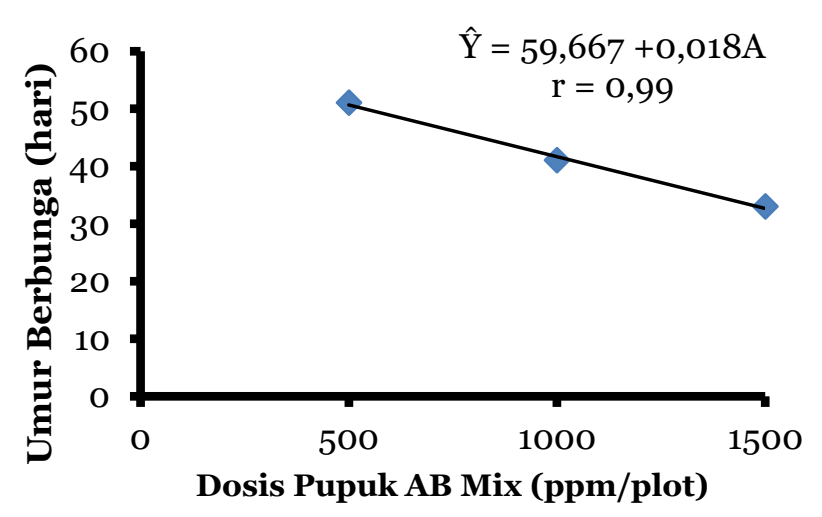

Gambar 2. Histogram Pemberian Pupuk AB Mix Terhadap Umur Berbunga Terung Ungu Umur 6 Minggu Setelah Tanam

Pengaruh berbagai pupuk organik cair terhadap umur berbunga terung ungu dapat dilihat pada kurva (Gambar 3) di bawah ini.

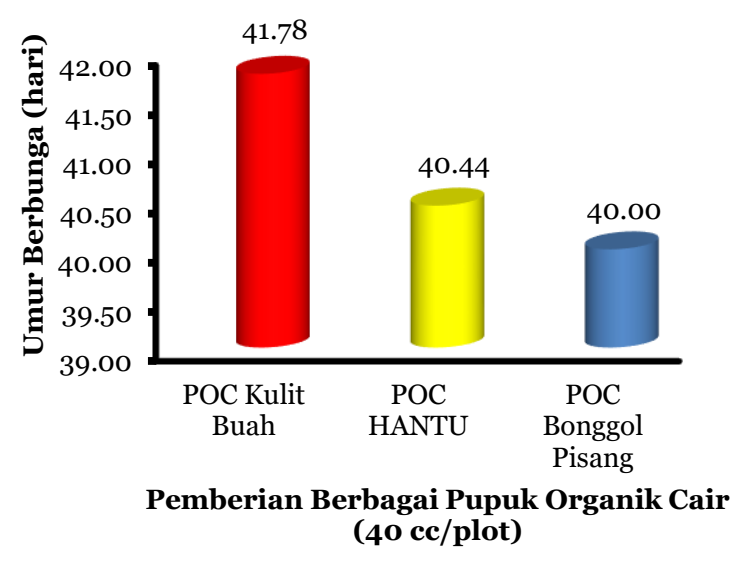

Gambar 3. Histogram Pemberian Berbagai Pupuk Organik Terhadap Umur Berbunga Terung Ungu Umur 6 Minggu Setelah Tanam

Pengaruh pemberian pupuk organik cair terhadap umur berbunga terung ungu diperoleh umur berbunga tercepat pada perlakuan $\mathrm{C}_{3}$ (POC bonggol pisang) yaitu 40,00 hari, sedangkan umur berbunga terlama diperoleh pada perlakuan $\mathrm{C} 1$ (POC kulit buah) yaitu 42,00 hari dan perlakuan C2 (POC HANTU) memperoleh 40,33 hari.

\section{Jumlah Bunga}

Dari hasil analisis sidik ragam dapat dilihat bahwa pemberian pupuk AB Mix menunjukkan pengaruh sangat nyata terhadap jumlah bunga terung ungu. Pemberian berbagai pupuk organik cair serta interaksi perlakuan pupuk AB Mix dengan berbagai pupuk organik cair menunjukkan pengaruh yang tidak berbeda yata terhadap jumlah bunga terung ungu. Hasil uji beda rata-rata pengaruh pupuk AB Mix dan berbagai pupuk organik cair terhadap jumlah bunga terung ungu dapat dilihat pada Tabel 5 berikut ini.
Tabel 5.

Jumlah Bunga tanaman Terung Ungu

\begin{tabular}{ccccc}
\hline $\mathrm{A} / \mathrm{C}$ & $\begin{array}{c}\mathrm{C}_{1} \\
\text { (buah) }\end{array}$ & $\begin{array}{c}\mathrm{C}_{2} \\
\text { (buah) }\end{array}$ & $\begin{array}{c}\mathrm{C}_{3} \\
\text { (buah) }\end{array}$ & $\begin{array}{c}\text { Total } \\
\text { (buah) }\end{array}$ \\
\hline $\mathrm{A}_{1}$ & 3,00 & 3,00 & 3,00 & $9,00 \mathrm{~b}$ \\
$\mathrm{~A}_{2}$ & 4,00 & 4,00 & 5,00 & $13,00 \mathrm{a}$ \\
$\mathrm{A}_{3}$ & 5,00 & 5,00 & 4,00 & $14,00 \mathrm{a}$ \\
\hline Rerata & $12,00 \mathrm{a}$ & $12,00 \mathrm{a}$ & $12,00 \mathrm{a}$ & - \\
\hline
\end{tabular}

Dari Tabel 5 diatas dapat dilihat bahwa pemberian pupuk $\mathrm{AB}$ Mix secara tunggal dengan perlakuan $1500 \mathrm{ppm} /$ plot (A3) menghasilkan jumlah bunga tertinggi yaitu 14 bunga, tidak berbeda nyata dengan perlakuan A2 (1000 ppm/plot), namun berbeda nyata dengan pelakuan A1 (500 ppm/plot). Demikian juga dengan perlakuan A2 dan A1 yang menunjukkan saling berbeda nyata. Pemberian berbagai pupuk organik secara tunggal dengan dosis 40cc/plot $\left(\mathrm{C}_{3}\right)$ POC bonggol pisang menghasilkan jumlah bunga tertinggi yaitu 12,00 bunga, tidak berbeda nyata dengan $\mathrm{C}_{2}$ (POC HANTU) dan $\mathrm{C} 1$ (POC kulit buah), serta perlakuan $\mathrm{C}_{2}$ dengan $\mathrm{C}_{1}$ juga menunjukkan tidak berbeda nyata. Interaksi pemberian pupuk $\mathrm{AB}$ Mix dan berbagai pupuk organik cair menunjukkan pengaruh yang tidak nyata. Secara visual jumlah bunga tertinggi diperoleh pada kombinasi perlakuan $\mathrm{A}_{2} \mathrm{C}_{3}$, yaitu dengan 5,00 tangkai bunga. Pengaruh pupuk AB Mix terhadap jumlah bunga terung ungu dapat dilihat pada kurva Gambar 4.

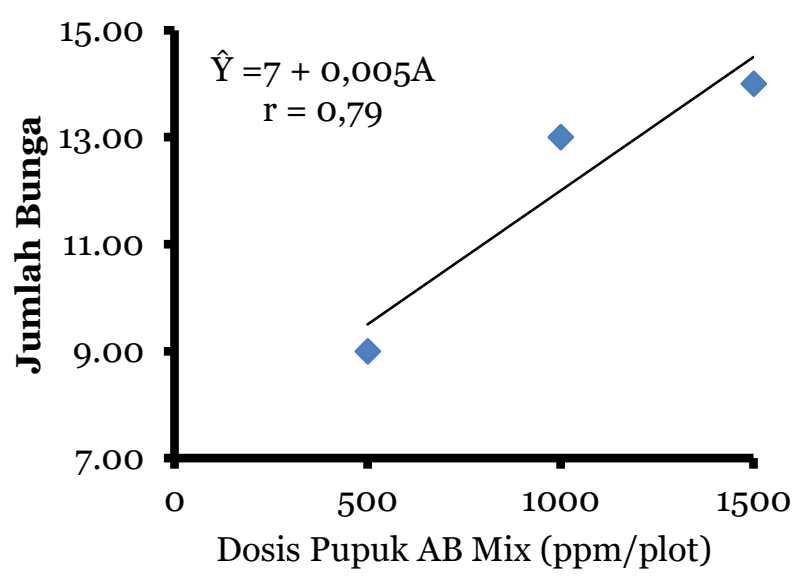

Gambar 4. Histogram Pemberian Pupuk AB Mix Terhadap Jumlah Bunga Terung Ungu Umur 6 Minggu Setelah Tanam

Analisis regresi pengaruh pemberian pupuk $A B$ Mix terhadap jumlah bunga terung ungu diperoleh kurva regresi linier dengan persamaan $\hat{Y}=7+0,005$ A dengan $r=0,79$ seperti dapat dilihat pada Gambar 4 di atas.

Dari hasil analisis sidik ragam menunjukkan pertumbuhan tinggi tanaman terung umur pada umur 2,4 dan 6 minggu setelah tanam tidak berpengaruh nyata. Dimana, rerata pertumbuhan tanaman tertinggi pada perlakuan A3 (1500 $\mathrm{ppm} / \mathrm{plot}$ ), sedangkan rerata pertumbuhan tinggi 
tanaman terendah diperoleh pada perlakuan A1 (500 ppm/plot). Selain itu pada diameter batang juga menunjukkan bahwa pengaruh pemberian pupuk $\mathrm{AB}$ Mix terhadap diameter batang terung ungu tidak berpengaruh nyata pada umur 2, 4 dan 6 minggu setelah tanam.

Tidak adanya pengaruh yang nyata pada parameter amatan tinggi tanaman dan diameter batang, diduga karena konsentrasi AB Mix yang diberikan tidak mencukupi untuk kebutuhan pertumbuhan maupun perkembangan tanaman terung ungu, yang menyebabkan proses metabolisme tanaman kurang baik. Akibatnya, tidak memacu proses pertumbuhan tanaman terung ungu. Menurut (Purba, Safruddin and Gunawan, 2019) dari hasil penelitian yang sudah dilakukan dapat dilihat bahwa pemberian kosentrasi nutrisi yang sesuai dapat menghasilkan pertumbuhan dan perkembangan tanaman terung ungu yang optimal. Selain itu, pertumbuhan dan perkembangan tanaman juga tidak lepas dari lingkugan tumbuh.

Pertumbuhan dan perkembangan tanaman dapat dipengaruhi oleh faktor eksternal dan faktor internal. Menurut Buntoro, dkk (2014) dalam (Purba, Safruddin and Gunawan, 2019) faktor eksternal merupakan faktor yang disebabkan dari luar tanaman dapat berupa faktor lingkungan. Faktor internal atau faktor yang berasal dari dalam tanaman dapat berupa faktor fisiologis dan genetika tanaman. Semua hara yang terkandung pada nutrisi hidroponik adalah unsur esensial yang diperlukan tanaman dalam pertumbuhan dan perkembangannya. Apabila unsur hara makro dan mikro tidak lengkap ketersediaannya, dapat menghambat pertumbuhan dan perkembangan tanaman.

Berdasarkan hasil analisis sidik ragam menunjukkan bahwa pengaruh pemberian pupuk $\mathrm{AB}$ Mix terhadap jumlah daun terung ungu tidak berpengaruh nyata pada umur 2 dan 4 minggu setelah tanam. Namun pada umur 6 minggu setelah tanam menunjukkan pengaruh yang nyata. Hal ini disebabkan oleh pertumbuhan akar yang baik yang mampu menyerap nutrisi $\mathrm{AB}$ Mix secara efektif sehingga kebutuhan unsur hara pada tanaman dapat tercukupi dan membuat pertumbuhan jumlah daun meningkat. Adanya pengaruh nyata pada pemberian Nutrisi AB- Mix, diduga Nutrisi AB- Mix mengandung unsur makro ( $\mathrm{N}, \mathrm{P}, \mathrm{K}, \mathrm{Ca}, \mathrm{Mg}, \mathrm{S})$ dan mikro (Fe, Mn, Cu, Zn, Bo, Mo) lengkap, bahan 100\% larut dalam air, sehingga mudah diserap tanaman dan memenuhi kebutuhan nutrisi tanaman (Sari, Safruddin and Purba, 2020). Jumlah daun juga meningkat karena adanya hubungan dengan tinggi tanaman. Kedua parameter, yakni tinggi tanaman dan jumlah daun tanaman memiliki hubungan yang erat. Jumlah daun berhubungan dengan pertumbuhan batang atau tinggi tanaman dimana batang tersusun dari ruas yang merentang diantara buku-buku batang tempat melekatnya daun. Jumlah buku dan ruas sama dengan jumlah daun. Sehingga dengan bertambah panjangnya batang akan menyebabkan jumlah daun yang terbentuk juga semakin banyak (Ainina and Aini, 2018).

Pada parameter pengamatan umur berbunga dan jumlah bunga pemberian pupuk AB Mix menunjukkan pengaruh nyata. Pada fase generatif ini pupuk $\mathrm{AB}$ Mix berperan penting dalam proses perkembangan tanaman. Dalam pupuk AB Mix terdapat kandungan fosfor didalamnya yang mana berperan dalam pembentukan bunga. Menurut Hendra, dkk (2014) dalam (Furoidah, 2018) fosfor merupakan sumber energi bagi tanaman dan mineral ini berperan dalam proses pertumbuhan bunga, buah dan biji sehingga sangat dibutuhkan pada fase perumbuhan generatif. Fosfor jugamemacu pembentukan akar yang berpengaruh terhadap kemampuan akar dalam mengabsorbsi nutrisi yang tersedia untuk pembentukan jumlah bunga.

Adanya pengaruh yang tidak nyata pada perlakuan pemberian berbagai pupuk organik cair terhadap parameter pengamatan tinggi tanaman, diameter batang, jumlah daun, dan jumlah bunga, hal ini mungkin disebabkan oleh dosis berbagai pupuk organik cair yang diterapkan masih terlalu rendah dan dimungkinkan diterapkan dosis yang lebih tinggi untuk meningkatkan pertumbuhan dan perkembangan bunga terung ungu. Tanaman akan tumbuh dengan baik apabila jumlah unsur hara yang diberikan dalam jumlah yang seimbang dan sesuai dengan kebutuhan tanaman (Djiwosaputro, 2012) dalam (Satriawi, Tini and Iqbal, 2020).

Parameter pengamatan umur berbunga menunjukkan pengaruh yang nyata, dapat dilihat pada gambar 3, hal ini disebabkan karena pada pupuk organik cair mengadung berbagai unsur hara makro dan mikro yang bagus untuk mempercepat pertumbuhan bunga pada tanaman. Pemberian perlakuan berbagai pupuk organik cair memberikan pengaruh sangat nyata pada umur berbunga terung ungu, yang mana dapat dilihat pada Gambar 3 umur berbunga tercepat dihasilkan pada perlakuan pemberian pupuk organik cair bonggol pisang (C3) yaitu 40,00 hari dan umur berbunga terlama dihasilkan pada perlakuan pupuk organik cair buah yaitu 42,00 hari. Hal ini disebabkan karena pada berbagai pupuk organik cair khususnya pada pupuk organik cair bonggol pisang terdapat unsur hara makro yang bagus untuk pertumbuhan bunga, salah satunya unsur phosfor. Pupuk Organik Cair (POC) bonggol pisang memiliki peranan dalam masa pertumbuhan vegetatif tanaman dan tanaman toleran terhadap penyakit. Dimana, kadar asam 
fenolat yang tinggi membantu pengikatan ion-ion $\mathrm{Al}$, Fe dan Ca sehingga membantu ketersediaan fosfor (P) yang berguna pada proses pembungaan dan pembentukan buah (Setianingsih, 2009) dalam (Chaniago, Purba and Utama, 2017).

Menurut (Suhastyo et al., 2013) bahwa bonggol pisang mengandung karbohidrat (66\%), protein, air, dan mineral-mineral penting. Bonggol pisang mempunyai kandungan pati. 45,5\% dan kadar protein 4,35\%. Bonggol pisang mengandung mikroba pengurai bahan organik antara lain Bacillus sp, Aeromonas sp, dan Aspergillus nigger dan bonggol pisang mengandung 3087 ppm NO3, 1120 ppm NH4, 439 ppm $\mathrm{P}_{2} \mathrm{O}_{5}$ dan 574 ppm K2O.

Pada parameter pengamatan tinggi tanaman dan diameter batang tanaman terung ungu umur 6 MST menunjukkan pengaruh yang tidak berbeda nyata namun dilihat dari tabel hasil uji beda rataan pupuk organik cair yang berpengaruh terhadap tinggi tanaman dan diameter batang. Dimana, POC HANTU menghasilkan tinggi tanaman tertinggi 23,04 $\mathrm{cm}$ serta diamater batang terbesar 6,31 $\mathrm{mm}$. Hal ini mengindikasikan bahwa perlakuan POC HANTU sangat baik digunakan untuk meningkatkan jumlah unsur hara untuk membantu mempercepat pertumbuhan tanaman dan mempercepat pencapaian tinggi tanaman. Sejalan dengan penelitian Nusi (2013) dalam (Rambe, Hasibuan and Batubara, 2018), menyimpulkan bahwa pertumbuhan tinggi tanaman nampak pada setiap tingkatan perlakuan dosis pupuk yang diberikan. Hasil ini menjelaskan bahwa perlakuan POC HANTU pada umur $6 \mathrm{MST}$ dengan dosis $40 \mathrm{cc} / \mathrm{plot}$ dapat memacu pertumbuhan tinggi tanaman dan diameter batang tanaman terung ungu.

Pada parameter pengamatan jumlah daun tanaman terung ungu umur 6 MST menunjukkan pengaruh yang tidak berbeda nyata namun dilihat dari tabel hasil uji beda rataan, pupuk organik cair yang berpengaruh terhadap jumlah daun tanaman terung ungu. Dimana, POC kulit buah menghasilkan jumlah daun terbanyak, yaitu sebesar 12,17 helai. Gardener dkk (2008) dalam (Farida and Daryono, 2012) menyatakan bahwa pertambahan jumlah daun tanaman terjadi karena pembelahan sel, peningkatan jumlah sel dan pembesaran ukuran sel yang membutuhkan energi dalam bentuk ATP. Phospat merupakan unsur yang dibutuhkan dalam pembentukan ATP tersebut. Sehingga Meirina (2014) dalam (Farida and Daryono, 2012) menyatakan bahwa unsur Kalium berperan penting dalam membuka dan menutupnya stomata serta berperan sebagai activator dari beberapa enzim yang terlibat didalam sintesis protein dan karbohidrat. Apabila $\mathrm{K}$ meningkat, maka karbohidrat juga meningkat sehingga dapat digunakan untuk meningkatkan pertambahan jumlah daun tanaman .Sehingga dalam hal ini, unsur Nitrogen, Phospat dan Kalium yang ada dalam POC kulit buah dibutuhkan oleh tanaman terung ungu untuk meningkatkan pertambahan jumlah daun tanaman terung ungu.

Interaksi yang tidak berpengaruh nyata diduga tidak adanya saling mempengaruhi antara perlakuan pemberian pupuk AB Mix dengan berbagai pupuk organik cair. Kedua pupuk tersebut hanya menunjukkan pengaruhnya masing-masing, dan kalau dianalisis secara statistik menunjukkan pengaruh yang tidak nyata pada taraf signifikasi $5 \%$. Kemungkinan lain yang menyebabkan tidak adanya pengaruh interaksi yang nyata dari semua parameter yang diamati diduga karena interaksi kedua perlakuan tidak saling mendukung satu sama lain dan kedua perlakuan bekerja sendiri-sendiri sehingga efeknya akar tanaman tidak merespon.

Tidak dimilikinya hubungan interaksi pada pupuk AB Mix dan berbagai pupuk organik cair yang digunakan, kemungkinan karena adanya perbedaan faktor dari keduanya sehingga tidak saling mempengaruhi. Dimana, pada setiap faktor mempunyai sifat yang beda berpengaruh dari sifat kerjanya, maka akan menghasilkan hubungan yang berpengaruh dalam mempengaruhi pertumbuhan tanaman. Apabila salah satu faktor pengaruhnya lebih kuat dari faktor lainnya maka faktor tersebut akan tertutupi oleh faktor lainnya. Apabila terdapat dua faktor yang diteliti sedangkan salah satu faktor lebih dominan pengaruhnya dibanding faktor yang lainnya, maka faktor yang lemah akan tertutupi dan masing-masing faktor mempunyai sifat dan kerja yang berbeda dalam mendukung pertumbuhan tanaman.

\section{SIMPULAN DAN SARAN}

Pemberian pupuk AB Mix tidak berpengaruh nyata pada pengamatan tinggi tanaman dan diameter batang, namun berpengaruh nyata pada pengamatan jumlah daun, umur berbunga dan jumlah bunga. Dimana, konsentrasi AB Mix terbaik A3 (1500 ppm/plot) menghasilkan tinggi tanaman 23,27 cm, jumlah daun 12 helai, diameter batang $6,33 \mathrm{~mm}$, umur berbunga 30 hari dan jumlah bunga 5 tangkai. Pemberian berbagai pupuk organik cair dengan dosis $40 \mathrm{cc} /$ plot tidak berpengaruh nyata hampir di semua parameter pengamatan, kecuali pada parameter pengamatan umur berbunga. Dimana, pupuk organik cair terbaik adalah $\mathrm{C}_{3}$ (pupuk organik cair bonggol pisang) yang menghasilkan tinggi tanaman 21,31 cm, jumlah daun 12,00 helai, diameter batang 6,02 mm, umur berbunga 40,00 hari dan jumlah bunga 4 tangkai. Selain itu, interaksi pemberian pupuk AB Mix dengan berbagai pupuk organik cair tidak berpengaruh nyata terhadap semua parameter pengamatan yang diamati. 
Jurnal AGROTEK Vol. 8, No. 2, 2021/Respon Pemberian Pupuk AB Mix dan Berbagai Pupuk Organik Cair Terhadap Pertumbuhan Tanaman Terung Ungu Secara Hidroponik dengan Sistem Wick/Deddy Wahyudin Purba \& Jian Maulana

\section{DAFTAR RUJUKAN}

Ainina, A. N. and Aini, N. (2018) 'Konsentrasi Nutrisi Ab Mix Dan Media Tanam Terhadap Pertumbuhan Dan Hasil Tanaman Selada Merah (Lactuca sativa L. var. crispa) Dengan Sistem Hidroponik Substrat', Jurnal Produksi Tanaman, 6(8), pp. 1684-1693.

Aisyah, A. (2020) Pengaruh Pemberian Kombinasi Pupuk Organik dan Pupuk Npk Terhadap Pertumbuhan dan Hasil Tanaman Terong Ungu (Solanum Melongena L.). Universitas Brawijaya.

Chaniago, N., Purba, D. W. and Utama, A. (2017) 'Respon Pemberian Pupuk Organik Cair (POC) Bonggol Pisang dan Sistem Jarak Tanam terhadap Pertumbuhan dan Produksi Kacang Hijau (Vigna radiata L.)', Jurnal Penelitian Pertanian BERNAS.

Farida and Daryono (2012) 'Pengaruh Dosis Poc Limbah Kulit Pisang Terhadap Pertumbuhan dan Hasil Tanaman Pakcoy (Brassica rapa L)', (2011). Available at: https://media.neliti.com/media/publications/341184-pengaruhdosis-poc-limbah-kulit-pisang-t-6980aff6.pdf.

Furoidah, N. (2018) 'Efektivitas Nutrisi Ab Mix Terhadap Hasil Dua Varietas Melon', Agritrop: Jurnal Ilmu-Ilmu Pertanian (Journal of Agricultural Science), 16(1), p. 186. Available at: https://doi.org/10.32528/agr.v16i1.1562.

Habibie (2020) 'Pengaruh Pemberian Pupuk Cantik dan Pupuk Organik Cair Hormonik Terhadap Pertumbuhan dan Hasil Tanaman Terong Ungu (Solanum melongena L.) Varietas Yuvita F1', Jurnal AGRIFOR, XIX(1), pp. 135-148.

Marjenah, M. et al. (2018) 'Pemanfaatan Limbah Kulit BuahBuahan Sebagai Bahan Baku Pembuatan Pupuk Organik Cair', ULIN: Jurnal Hutan Tropis, 1(2), pp. 120-127. doi: 10.32522/ujht.v1i2.800.

Prastya, Y. and Palupi, P. (2017) 'Pengaruh Dosis Pupuk Kandang Sapi dan Pupuk Organik Cair Terhadap Pertumbuhan dan Hasil Tanaman Terung Ungu (Solanum melongena L.)', Jurnal Viabel Pertanian, 11(1), pp. 23-34.

Purba, D. W. and Patimah, S. (2020) 'Respon Pertumbuhan Dan Produksi Tanaman Terung Ungu (Solanum melongena L) Secara Hidroponik Sistem Wick Terhadap Pemberian Nutrisi Ab Mix Dan Nutrisi Ekstrak Daun Kelor', Prosiding Seminar Nasional Multidisiplin Ilmu Universitas Asahan ke-4 Tahun 2020, (September), pp. 986-997.

Purba, D. W., Safruddin and Gunawan, H. (2019) 'Mnvhmfjhve', Prosiding Seminar Nasional Multidisiplin Ilmu Universitas Asahan ke-3 2019, pp. 781-789.

Rambe, M. K., Hasibuan, S. and Batubara, L. R. (2018) 'Respon Pertumbuhan Dan Produksi Tanaman Sawi Kailan (Brassica Oleraceae) Terhadap Pemberian Pupuk Organik Cair Hormon Tanaman Unggul (Hantu) Dan Pupuk Urea', BERNAS Agricultural Research Journal, 14(2), pp. 69-76.

Sari, S. W., Safruddin, S. and Purba, D. W. (2020) 'Pengaruh Pemberian Ekstrak Daun Kelor Dan Nutrisi Ab-Mix Terhadap Pertumbuhan Dan Produksi Tanaman Seledri (Apium Graveolens)', Jurnal Bernas, 15(3), pp. 22-31.

Satriawi, W., Tini, E. W. and Iqbal, A. (2020) 'Pengaruh Pemberian Pupuk Limbah Organik Terhadap Pertumbuhan Dan Hasil Tanaman Mentimun (Cucumis Sativus L.)', Jurnal Penelitian Pertanian Terapan, 19(2), p. $116 . \quad$ doi: 10.25181/jppt.v19i2.1407.

Suhastyo, A. A. et al. (2013) 'Studi mikrobiologi dan sifat kimia mikroorganisme lokal (MOL) yang digunakan pada budidaya padi metode Sri (System of rice intensification)', Sainteks Volume, 10(2), pp. 29-39.

Suhendra, Safruddin and Gunawan, H. (2019) 'Pengaruh Pemberian
Pupuk Organik Cair (Poc) Hantu dan Npk Cair Gandastar Terhadap Pertumbuhan dan Produksi Tanaman Mentimun (Cucumis Sativus L.)', BERNAS Agricultural Research Journa, 15(1), pp. 115-125. 